\title{
Narrating Modern War: Technology and the Aesthetics of War Literature
}

\author{
Martin Löschnigg
}

Department of English, University of Graz, Heinrichstrasse 36, A-8010 Graz, Austria

https://orcid.org/0000-0003-1330-7880

martin.loeschnigg@uni-graz.at

This essay analyses how since the early twentieth century war novels and memoirs have reflected the challenges which modern warfare poses to narrative. Mechanized warfare, I argue, resists the narrative encoding of experience, creating a crisis of narrative that is frequently made explicit in the assertion, on the part of novelists and memoirists, that the actual experience of combat cannot be narrated. Thus, for instance, the nature of warfare on the Western Front 1914-1918, characterized by the fragmentation of vision in the trenches and the exposure of soldiers to a continuous sequence of acoustic shocks, had a disruptive effect on perceptions of time and space, and consequently on the rendering of the chronotope in narrative accounts of the fighting. Since then, modern military technology has increasingly generated a sense that wars have acquired a dynamic of their own. The 'cinematic' nature of technological warfare and the resulting loss of individual agency have suspended the order-creating and meaning-creating function of narrative, leading, in extremis, to the representational impasse emphasized by trauma theory. In my discussion of selected war writings, I shall show how the 'cognitive narratology' of modern warfare can be applied to the analysis of aesthetic manifestations in war literature and the 'crisis of language' underlying (literary) modernity and postmodernity.

Keywords: literature and technology / World War I / war novel / narrative structure / war technology / crisis of representation

As Margot Norris states in her book Writing War in the Twentieth Century, modern wars have been "phenomenologically and ontologically discontinuous" with previous conflicts. In particular, she claims, "modern weapons technology has fundamentally altered the locus of agency" (16). For the first time, and on a massive scale, this could be observed in the case of trench fighting and the war of attrition on the Western Front in the First World War. There, agency, according to the testimony of combatants, seemed to have shifted from humans to the oppressive predominance of the material aspects of warfare, especially 
new weapons (see Leed), generating a "sense of the war as a machine and of all soldiers as its victims" (Hynes 439). Since then, modern military technology has rapidly transformed battles in a way that transcends traditional modes of perception, revealing the incompatibility of modern and archaic experiences of combat. It has generated and intensified feelings on the part of combatants that wars have acquired a dynamic of their own, to an extent that may sometimes cause soldiers to lose their hold on reality.

This essay will discuss the implications of technologized warfare for war narratives. In particular, I shall analyze how mechanized war affects the spatial and temporal orientation of narratives, focusing on the Great War of 1914-1918 as the first industrialized war in history. However, I shall also provide glimpses at selected examples of writing from the US wars in Vietnam, like Michael Herr's 'new journalistic' Dispatches (1978) and Tim O'Brien's novel Going After Cacciato (1975), and in Iraq, like Kevin Powers's novel The Yellow Birds (2012). I should add that, whether factual or fictional, all texts mentioned are based on their authors' actual war experience, either as combatants or, in the case of Herr, as a frontline reporter. Mechanized warfare, I want to argue, resists the narrative encoding of experience, creating a crisis of narrative that is frequently made explicit in the assertion, on the part of novelists and memoirists, that the actual experience of combat cannot be narrated (see McLoughlin, "War and Words").

Obliquely, it seems, this crisis of narrative is also expressed through the structure and technique of war narratives. A narratological investigation of such narratives yields a very diverse picture as to how these texts struggle with giving narrative form to the experience of war, and particularly that of actual combat. On the discursive level, these narrativisings can be described in terms of the categories provided by 'classical' structuralist narratology, yet for my analysis I also want to draw on approaches in cognitive narratology, like for instance Monika Fludernik's Towards a Natural Narratology (1996). As Fludernik claims, cognitive frames that relate to basic perspectives on human experience become functional in the mediation of that experience through narrative discourse. In this sense, the narrative rendering (and 'reliving') of the frontline in (autobiographical) accounts may be grasped in terms of a frame model. While modern war tends to disrupt 'telling frames' dependent on parameters like chronology, causality and teleology, its spatial and temporal specifics foster a disrupted rendering of the war whose 'experiential' framing aims at conveying the immediacy of disoriented experience. The 'experientiality' of war narratives may thus be 
enhanced through the fragmentation of the chronotope and (in homodiegetic narratives) the blurring of boundaries between experiencing and narrating selves, strategies which engender a continuity of experience and narration despite the time-lag of the narrative act as such. Structurally, this is evident in various forms of discontinuity and fragmentation that are prominent, for instance, in modernist writing about the First World War. One memorable (although still much-neglected) example is Edlef Köppen's novel Heeresbericht (1930), whose montage technique contrasts a disjointed account of the protagonist's experiences at the Western Front with quotations from (propagandist) publications and impersonal (and euphemistic) military communiqués (hence the title). ${ }^{1}$ However, modernist writing from that war in particular presents a paradox in that extreme formal consciousness is to signify lack of composition in an attempt at approaching the 'raw' contingency of events. Later war narratives, including Herr's Dispatches or Powers's The Yellow Birds, often use the same montage technique as Köppen's novel, emphasizing equally strongly the alienation of the soldier as a $\operatorname{cog}$ in the wheels of the war machine.

Speaking of the 'war-machine,' I am using the term in the sense of conceptions and depictions of war as a technologized, self-reinforcing event, not in the sense of "the military system of rules and regulations" (McLoughlin, Authoring War 182) which, in its rigid abstraction, is indifferent to the needs of the individual. Neither am I using the term in the sense of Deleuze and Guattari (in Nomadology) to refer to social assemblages either incorporated by or directed against the state. What I need to stress here, too, is that the 'war machine' in my understanding of the term is not only a prominent topos in war writing, including novels, memoirs, short stories and poems, but also includes developments to filmic and 'virtual' media productions. These developments, it should be added, reached a first culmination in the Persian Gulf conflict of 1991, when the real-time circulation of images intertwined the war and its media-coverage in a way that created a sense of selfdriven events with their own dynamic, while at the same time producing an effect of virtual happenings detached from real-life experience (see Baudrillard).

Let me come to the question of the chronotope in modern war writing: in spatial terms, modern warfare is characterized by a fragmentation of vision on the level of the actual fighting, and by panoramic

${ }^{1}$ A translation into English was published by J. Cape \& H. Smith in 1931 under the title Higher Command. 
abstraction on the level of strategic planning and observation. While the sites of battle have greatly extended, the individual soldier's range of vision is normally extremely limited. In the First World War, periscopes and aerial photographs were used in partial compensation, while recent computer technology has opened up an enormous range of possibilities for the virtual depiction of battlefields. One characteristic that applied to the Western Front in 1914-1918 and - to some extent also to later wars like those in Vietnam or Iraq - was that the enemy remained invisible most of the time. It was therefore impossible for soldiers to get 'the whole picture', literally and in the sense of a contextualized understanding of their situation. The resulting feelings of disorientation, and the impression that the fighting had come loose from the spatial coordinates of human action, are memorably expressed in Death of a Hero, a novel by English Great War veteran Richard Aldington:

The fighting was so impersonal as a rule that it seemed rather a conflict with dreadful hostile forces of Nature than with other men. You did not see the men who fired the ceaseless hails of shells on you, nor the machine-gunners who swept away twenty men to death in one zip of their murderous bullets, nor the hands which projected trench-mortars that shook the earth with awful detonations, nor even the invisible sniper who picked you off mysteriously with the sudden impersonal 'ping!' of his bullet. (292)

In modern warfare, the scarcity of visual points of orientation along the frontline goes hand in hand with an intensification of acoustic stimuli. When asked to describe the sensorium of the trenches, English writer and Great War veteran Robert Graves famously replied: "[Y] ou can't communicate noise. Noise never stopped for one moment - ever" (cited in Fussell 170).

Modern war is also apt to disrupt an individual sense of time. Along the Western Front 1914-1918, as well as in later wars, long 'empty' stretches of time spent in waiting or routine typically alternated with extremely compressed moments of combat. This is how Aldington describes the experience of the protagonist in Death of a Hero: "For Winterbourne the battle was a timeless confusion, a chaos of noise, fatigue, anxiety, and horror. He did not know how many days and nights it lasted, lost completely the sequence of events, found great gaps in his conscious memory" (376). Imposing 'machine time' and a technological mode of perception on human action and reaction, trench warfare amounted to a physiological conquest of individuals. Correspondingly, soldiers are sometimes portrayed as automata, as 'micro-machines' within the macro-machine, as in Arnold Zweig's 
novel Erziehung vor Verdun: "Die Infanteristen hier sahen aus wie ... Fabrikarbeiter der Zerstörung; sie hatten alle die Gleichgültigkeit, die Industrie und Maschine dem Menschen aufpressen" (129; "the infantry here looked like ... factory-hands of destruction; they all had the indifference which industry and the machine imprint on man"). ${ }^{2}$ The 'machine' took over, structuring reality as well as its symbolic encoding by impairing or even eliminating spatial and temporal orientation. Again, this holds equally strongly for later wars, like the war in Vietnam, as is amply testified by the literature of that war.

During intensive phases of combat in particular, those categories of consciousness and memory dependent on the chronotope are prone to affect. Modern war thus resists especially the chronological structuring required in order to express experience in narrative form (cf. Hüppauf, esp. 209, 219-221), suspending the capacity of narrative to create order and meaning. As Jan Mieszkowski has noted about the First World War, that war "no longer respect[ed] epic conventions of time, space and pacing ... [but was] distinguished [instead] by radical discontinuity" (152). As a result, says Samuel Hynes, "[a] writer might experience the war, [but] he could not put his experience into a narrative form - a story with causal connections, direction, and a resolving ending - because that would give it the significance it did not possess, or did not reveal" (106).

Modern warfare undermines important parameters of conventional (realistic) narrative: spatial orientation, linear chronology, causality, teleology and the assumption of a transparency of language with regard to its referential objects (see Löschnigg). The disintegration of these parameters counters those elements and techniques which war narratives may use to produce coherence and a sense of purpose, and which are thus significant for the authentification of the narrative. These are, first, an emphasis on historical facticity (also in novels) which suggests a purely mimetic function, avoiding the impression of any attempts at ideological manipulation; second, the authority of direct experience established by the testimony of the 'écrivain combatant' and, finally, the very 'plain style' of war narratives. These 'authentification devices' have helped to produce powerful cultural imaginaries, in particular the phenomenon which James Campbell has called "combat Gnosticism," i.e. the privileging of the frontline fighter's perspective as the only 'true' perspective on the war, to the marginalization or even exclusion of others.

World War I narratives often illustrate cultural historian Modris Eksteins's remark that on the Western Front 1914-1918 “men no lon-

\footnotetext{
${ }^{2}$ This and other German passages are translated by Martin Löschnigg.
} 
ger made war; war was made on men" (183). Guy Chapman's Great War memoir $A$ Passionate Prodigality speaks of an "almost complete dehumanizing of war" (274-275). For Ernst Jünger, battle did not only employ machines; it was also suffused by the spirit that had created them: "[Die Schlacht] wird als Ganzes vom Geist durchsetzt, der die Maschinen schafft." ("Feuer und Bewegung" 116). Indeed, Jünger's war writings, besides conveying the author's fascination with an austere beauty he perceives in the sights and sounds of the frontline, at times also create a sense of a quixotic struggle against anonymous forces of destruction, as is also indicated by the very title of The Storm of Steel. His description of artillery fire as an "occurrence which was completely beyond our experience," "ein völlig außerhalb der Erfahrung liegende[s] Ereignis" (In Stablgewittern 9), may be seen as a case in point. Similarly, Aldington refers to a bombardment as "indescribable" and to be rendered only metaphorically as "a stupendous symphony of sound" (373).

Through its apparent self-dynamics and its overwhelming scale, the new industrialized warfare greatly intensified a crisis of linguistic representation which had already been expressed in literature and the thinking about language before the war. First World War writing often reveals a sense of a representational impasse and the feeling that the war eroded linguistic resources. Narratologically speaking, as I have shown, trench fighting posed a challenge to conventional narrative, disrupting 'telling frames' dependent on parameters like chronology, causality and teleology. These parameters, in turn, require a unified vision and temporal orientation. Paul Virilio's 'dromological' study of modern war, War and Cinema: The Logics of Perception, argues that in the First World War, the technology of cinema began to replace the act of looking; in particular, the acceleration of war (hence his coinage of 'dromology') produced a new unity of time that was to be captured initially (and precariously) only in film. As David Williams has emphasized, many First World War narratives are indeed "governed largely by the implicit epistemology of film" (30), rendering a "cinematic form of memory" (6) which causes the past and the present to collapse in a "cinematic telescoping of time" (29). Aldington's Death of a Hero speaks of the protagonist "Winterbourne's hallucinated memories, where images and episodes met and collided like superimposed films" (344), and in Köppen's Heeresbericht memories of leave and home unwind before the protagonist's eyes like a film, "zu schnell gedreht, ungeschickt geschnitten, ... zu Bildchen, zu Fetzen zerrissen" ("too hastily shot, clumsily cut, ... torn to stills, to fragments") (148). 
Through its experimental use of montage techniques, Köppen's novel simulates the montage effect of technoid perception. The narrating subject has been overpowered by the object world, and the narrative voice has been destabilized, reduced to the discontinuous reporting of external action, and to the rendering of disconnected sense impressions and fragments of consciousness. The text thus bypasses narration, highlighting instead the chaotic immediacy of events, as in the following description of an attack:

Wie der letzte Rauch sich vom Boden gelöst hat, steht und liegt und kniet und kriecht und läuft und springt, graue lebendige Masse; der Feind. Und stürmt, Handgranaten hochgeschwungen, das Bajonett gereckt, gegen den Graben vor.

Da kläfft das Maschinengewehr neben Reisiger los. Da prasselt neben ihm Schnellfeuer aller Gewehre.

Herrgott, was geschieht! Dutzende von Franzosen werfen die Arme hoch und fallen rücklings zur Erde. Aber andere Dutzende dicht geballt drängen weiter vorwärts.

Die Feuer der Handgranaten zischen. Die Flammen der Artillerie rasen. Und: Franzosen, immer wieder neu: Franzosen: vorwärts.

Am Maschinengewehr schreit man durcheinander. Reisiger begreift kein Wort. (79-80)

(As soon as the last of the smoke has lifted from the ground there stands and lies and kneels and creeps and runs and jumps, grey living mass; the enemy. And storms, hand-grenades wielded high, bayonets pointing, against our trench.

Then the machine-gun beside Reisiger starts barking. Then beside him rapid fire from all rifles is pattering.

Good God, what's happening! Dozens of Frenchmen throw up their arms and fall backwards onto the ground. Yet dozens of others continue to press forward, tightly clustered.

The blasts of the hand-grenades are hissing. The flames of the artillery are racing. And: Frenchmen, always new Frenchmen: advance.

At the machine-gun there is confused shouting. Reisiger does not understand a single word.)

The use of the historical present in this passage signifies a reenactment of contingent experience through a discourse that implies a failure to narrativize events by relegating them to an epic past, and thus to convey a sense of closure. Köppen's narrative technique addresses the problem of rendering passing (or unassimilated) events into a fixed temporal configuration, and of mediating, through the narrative act, between multiple incidents and a unified story. The narrator's discourse resists 
a fixed position of identification, implying that the protagonist's traumatic experience cannot be conveyed through conventional modes of narrative but only through non-linearity, fragmentation and the 'performative' effect of the novel's language that arises from metaphor and the interplay of its different texts. 'Filmic' immediacy eclipses the integrating function of narrative voice (and the underlying memory factor) by focusing instead on a quasi-dramatic reenactment of traumatic experience. Heeresbericht thereby illustrates Norbert Bolz's contention that the First World War was in many respects "profoundly unepic" (das "Unepische schlechthin") (82).

Since the First World War, the growing mechanization of battle and increasing spatial and quantitative delimitation of warfare have further heightened the disorienting and fragmentary character of the individual war experience. Under different cultural and aesthetic auspices, therefore, writing from more recent wars, too, emphasizes the difficulty of rendering the frontline experience in narrative. Thus, Captain Rhallon in Tim O'Brien's Going After Cacciato speaks of the fragmentation of vision and the resulting epistemological limitations that apply in battle:

In battle, in a war, a soldier sees only a tiny fragment of what is available to be seen. The soldier is not a photographic machine. He is not a camera. He registers, so to speak, only those few items that he is predisposed to register and not a single thing more. Do you understand this? So I am saying to you that after a battle each soldier will have different stories to tell, vastly different stories, and that when a war is ended it is as if there have been a million wars, or as many wars as there were soldiers. (176)

Blending fantasy and reality, O'Brien's novel recounts the mission of Paul Berlin (a name reminiscent of Paul Bäumer, the protagonist in Remarque's All Quiet on the Western Front) and his squad to capture a deserter from the Vietnam War. Ending on an imaginary chase that leads as far as Paris, O'Brien's undermining of realist 'telling frames' accounts for the experience that in modern war " $[t]$ he facts were separate and haphazard and random, even as they happened, episodic, broken, no smooth transitions, no sense of events unfolding from prior events" (185). Cacciato's (the deserter's) elusiveness epitomizes the slippery hold on 'reality' induced by modern war, as addressed in a pep talk by Doc Peret remembered by Berlin:

What you remember is determined by what you see, and what you see depends on what you remember. ... A cycle that has to be broken. And this requires a fierce concentration on the process itself: Focus on the order of things, sort 
out the flow of events so as to understand how one thing led to another, search for that point at which what happened had extended into a vision of what might have happened. Where was the fulcrum? Where did it tilt from fact to imagination? (185)

Foregrounding questions of how the experience of the war could possibly be rendered in narrative, O’Brien's novel "expresses radical skepticism about both the nature and the narratability of war; indeed, it suggests that war is unintelligible and inexpressible" (Couser 2).

The same "radical skepticism" about conventional narrative applies to Michael Herr's Dispatches. Herr went to Vietnam in 1967, publishing his reports in various magazines before compiling his retrospective account in book form. Centering on the battle for Khe Sanh, a US Marines combat base, during the first half of 1968, Dispatches assembles 'flash' episodes that add up to a fragmented documentation in the clipped language and army slang in which the war was conducted. Like the First World War narratives here discussed, Herr's report emphasizes the invisibility of the enemy: "[I]t was us looking for him looking for us looking for him" (64); "instead of really ending, the battle vanished. The North Vietnamese collected up their gear and most of their dead and 'disappeared' during the night" (24). He also highlights the loss of agency experienced during intense moments of combat: "A lot of what people called courage was only undifferentiated energy cut loose by the intensity of the moment, mind loss that sent the actor on an incredible run" (69). The soldiers' sense of alienation is conveyed, as in Köppen's novel, through the analogy to film:

Between what contact did to you and how tired you got, between the farout things you saw or heard and what you personally lost out of all that got blown away, the war made a place for you that was all yours. Finding it was like listening to esoteric music, you didn't hear it in any essential way through all the repetitions until your own breath had entered it and become another instrument, and by then it wasn't just music anymore, it was experience. Lifeas-movie, war-as-(war) movie, war-as-life; a complete process if you got to complete it ... (67-68)

The image of the war as a self-determined, yet quasi-virtual event that emerges from this passage reiterates in Herr's book. It culminates in a reference to the US war effort as a "machine" that was "devastating" and "versatile": "It could do everything but stop" (74). This image of war as a force disengaged from human control (and thus not to be rendered in a narrative whose paradigms are revealing of authorial control) also sets the tone in Kevin Powers's Iraq novel The Yellow Birds: 
The war tried to kill us in the spring. As grass greened the plains of Nineveh and the weather warmed, we patrolled the low-slung hills beyond the cities and towns. We moved over them and through the tall grass on faith, kneading paths into the windswept growth like pioneers. While we slept, the war rubbed its thousand ribs against the ground in prayer. When we pressed onward through exhaustion, its eyes were wide and open in the dark. While we ate, the war fasted, fed by its own deprivation. It made love and gave birth and spread through fire.

Then, in summer, the war tried to kill us as the heat blanched all color from the plains. The sun pressed into our skin, and the war sent its citizens rustling into the shade of white buildings. It cast a white shade on everything, like a veil over our eyes. It tried to kill us every day, but it had not succeeded. Not that our safety was preordained. We were not destined to survive. The fact is, we were not destined at all. The war would take what it could get. It was patient. It didn't care about objectives, or boundaries, whether you were loved by many or not at all. While I slept that summer, the war came to me in my dreams and showed me its sole purpose: to go on, only to go on. And I knew the war would have its way. (Powers 3-4)

Powers, who served as a machine gunner with the US army in Iraq, depicts the traumatizing impact of the war experience in a narrative that breaks up linear chronology by constantly switching from the frontline to the postwar scene, when his protagonists try in vain to come to terms with what they have gone through. They realize that their integration into the 'war machine' has entailed an irrecoverable loss of self, making it impossible to see themselves as 'agents' in the events they have experienced. By implication, this also precludes the imposition of a conventional narrative order on these events.

'Anti-narratives' of this kind "still depend for effect on the presupposition of the traditional narrative line of choice" (Chatman 57), with chronological, causal and teleological coherence as its defining element. Undermining emplotment and the explanatory, analytico-referential assumptions of traditional (realist) narrative, these texts seem to refuse to make sense of the war. Instead, their disintegration of the realist image creates a form of hyper-realism which rests on the reduction of signification and the loss of meaning-creating elements in narrative. In terms of trauma theory, their aesthetic corresponds to a "trauma aesthetic" in narratives that mimic symptoms of trauma, such as temporal disruption or delay (Luckhurst 88). ${ }^{3}$ Seen as retrospective trauma nar-

${ }^{3}$ See also Anne Whitehead, who contends that the "impact of trauma can only be adequately represented by mimicking its forms and symptoms, so that, for instance, temporality and chronology collapse, and narratives are indirect and repetitive" (6). 
ratives, novels and memoirs about modern war often subvert "normal modes of artistic representation" also because survivors of trauma "live in durational rather than chronological time, they continue to experience the horrors of the past through internal shifts back in time and space rather than experiencing the past as differentiated from the present" (Vickroy 5).

The aesthetics of fragmentation, reduction and loss of agency in war writing since the early twentieth century must be seen within the framework of (post)modernist aesthetics in general. Of course, it is neither that the Great War did produce modernism in literature and the arts, nor is literary postmodernism primarily tied up with Vietnam. However, these wars did represent violent amplifications and refraction of (post)modernity, with mechanized warfare being the most intense manifestation of the dynamics of the machine age and its effects on human consciousness. ${ }^{4}$ Ultimately, the disintegration of 'telling frames' in many war narratives may be said to have produced a hyper-realism which made narrative fragmentation appear as the only possible form of narrativizing the disruptive experience of war. Byron Good has argued that normally "[n]arrative succeeds" in deflecting the full impact of crisis "by 'subjunctivizing' reality, by exploring the indeterminacy of reality" (153). There is some evidence in the writings of combatants that this mechanism seems to have failed in the case of the war experience. As the narrative means of structuring the contiguity of experience, and of thus relegating experience to a 'past reality' that could be grasped became dysfunctional, the war was enshrouded in myth, and the frontline assumed the status of a hyper-reality that made the relevance of all other experience dwindle. As Siegfried Sassoon's fictional alter ego, George Sherston, observes from an English war hospital, "[r] eality was on the other side of the Channel, surely" (525).

Rendering the 'reliving' of the frontline through the quasi-dramatic or filmic re-presentation of events, narratives of modern war indicate that the experience they describe cannot be relegated to the past, as the narrator's capacity for giving structure and meaning to that experience has been defeated, as it were, by the chaotic nature and overwhelming scale of events. These texts thus reflect the struggle for a new aesthetics adequate to a 'mother of all battles' (in the popular phrase) rather than a 'father of all things,' indicating a turning from 'war art' to a war against (the wrong) art and the traditional aesthetics underlying it.

${ }^{4}$ On the connection between violence and modernist aesthetics in particular see Sheehan. 


\section{WORKS CITED}

Aldington, Richard. Death of a Hero. London: Chatto \& Windus, 1929.

Baudrillard, Jean. The Gulf War Did Not Take Place. Trans. Paul Patton. Bloomington: Indiana University Press, 1995 [originally three essays in Libération and The Guardian, 1991].

Bolz, Norbert. Theorie der neuen Medien. Munich: Raben Verlag, 1990.

Campbell, James. "Combat Gnosticism: The Ideology of First World War Poetry Criticism." New Literary History 30.1 (1999): 203-215.

Chapman, Guy. A Passionate Prodigality: Fragments of Autobiography. London: Buchan \& Enright, 1933.

Chatman, Seymour. Story and Discourse: Narrative Structures in Fiction and Film. Ithaca, NY: Cornell University Press, 1978.

Couser, G. Thomas. "Going After Cacciato: The Romance and the Real War." Journal of Narrative Technique 13.1 (1983): 1-10.

Deleuze, Gilles, and Félix Guattari. Nomadology: The War Machine. Trans. Brian Massumi. New York: Columbia University Press, 1986.

Eksteins, Modris. Rites of Spring. The Great War and the Birth of the Modern Age. Boston: Houghton Mifflin, 1989.

Fludernik, Monika. Towards a 'Natural' Narratology. London, New York: Routledge, 1996.

Fussell, Paul. The Great War and Modern Memory. London, Oxford, New York: Oxford University Press, 1975.

Good, Byron. Medicine, Rationality and Experience: An Anthropological Perspective. Cambridge: Cambridge University Press, 1994.

Hüppauf, Bernd. "Der Erste Weltkrieg und die Destruktion von Zeit." Geschichte als Literatur: Formen und Grenzen der Repräsentation von Vergangenheit. Eds. Hartmut Eggert, Ulrich Profitlich, and Klaus R. Scherpe. Stuttgart: Metzler, 1990. 207-225.

Hynes, Samuel. A War Imagined: The First World War and English Culture. London: The Bodley Head, 1990.

Jünger, Ernst. "Feuer und Bewegung." Essays I: Betrachtungen zur Zeit. Stuttgart: Klett-Cotta, 2002 [1930]. 105-117.

Jünger, Ernst. In Stahlgewittern. Stuttgart: Klett-Cotta, 2014 [1920-1967].

Leed, Eric J. No Man's Land: Combat and Identity in World War I. Cambridge: Cambridge University Press, 1979.

Löschnigg, Martin. "How to Tell the War?: Trench Warfare and the Realist Paradigm in First World War Narratives." Anglica: An International Journal of English Studies 27. 3 (2018 [special issue: The Great War]): 143-161.

Luckhurst, Roger. The Trauma Question. London: Routledge, 2008.

McLoughlin, Kate. "War and Words." The Cambridge Companion to War Writing. Ed. K. M. Cambridge: Cambridge University Press, 2009. 15-24.

McLoughlin, Kate. Authoring War. The Literary Representation of War from the Iliad to Iraq. Cambridge: Cambridge University Press, 2011.

Mieszkowski, Jan. Watching War. Stanford/CA: Stanford University Press, 2012.

Norris, Margot. Writing War in the Twentieth Century. Charlottesville: University Press of Virginia, 2000.

Powers, Kevin. The Yellow Birds. New York: Little Brown, 2012.

Sassoon, Siegfried. The Complete Memoirs of George Sherston. London: Faber, 1972.

Sheehan, Paul. Modernism and the Aesthetics of Violence. Cambridge: Cambridge University Press, 2013. 
Virilio, Paul. War and Cinema: The Logics of Perception. Trans. Patrick Camiller. London: Verso, 1989 [1984].

Whitehead, Anne. Trauma Fiction. Edinburgh: Edinburgh University Press, 2004. Williams, David. Media, Memory and the First World War. Montreal, Kingston: McGill-Queen's University Press, 2009.

\section{Pripovedovanje o moderni vojni: tehnologija in estetika vojne literature}

Ključne besede: literatura in tehnologija / prva svetovna vojna / vojni roman / pripovedna struktura / vojaška tehnologija / kriza reprezentacije

V članku analiziram, kako so vojni romani in memoarji vse od začetka 20. stoletja odraz izzivov, ki jih sodobno vojskovanje predstavlja za pripoved. Pokažem, da se mehanizirano vojskovanje upira pripovednemu zapisu izkušnje in ustvarja pripovedno krizo, ki je pogosto eksplicitno prisotna v ugotovitvah romanopiscev in memoaristov, da pripoved o dejanski bojni izkušnji ni mogoča. Tako je imela denimo narava vojskovanja na Zahodni fronti (1914-1918), ki sta jo zaznamovala fragmentiranost pogleda v bojnih jarkih in izpostavljenost vojakov nenehnim akustičnim šokom, uničujoče učinke na dojemanje časa in prostora in posledično na podajanje kronotopa $\mathrm{v}$ pripovednih opisih bojevanja. Odtlej sodobna vojaška tehnologija vse bolj ustvarja občutek, da imajo vojne svojo lastno dinamiko. "Filmične« značilnosti tehnološkega vojskovanja in iz njih izhajajoča izguba osebne udeleženosti so ukinile pripovedno funkcijo vzpostavljanja reda in ustvarjanja pomena, kar je v skrajnem primeru privedlo do reprezentacijske mrtve točke, ki jo poudarja teorija travme. $\mathrm{V}$ pričujoči obravnavi izbranih zapisov o vojni bom pokazal, kako lahko »kognitivno naratologijo« sodobnega vojskovanja uporabimo za analizo pojavljanja estetskih prvin v vojni literaturi in "krize jezika», na kateri sloni (literarna) modernost in postmodernost.

1.01 Izvirni znanstveni članek / Original scientific article

UDK 82.0-311.6:94(100)"1914/1918"

DOI: https://doi.org/10.3986/pkn.v43.i1.08 